\title{
ERRATA.
}

Page 12, lines 16 and 17 , for one hundred read three hundred and for me thousand read six hundred.

Page 17 , line 2 , dele first letter in the line.

Page 168, line 12, page 177, lines 13 and 14, and page 271, line 10, for Lemna trisulca read Spirodela polynhiza.

Page 209 , line 2 of foot-note, after but insert represchts.

Page 256, line 7, and page 266, line 19: snowi n. s. has been shown to be hieroglyphica, o'.

Page 257, insert as line 8 as follows: -ken to the office produced young in ten days. The

Page 272, line 13, for $P$. biguttatus read Pompilus biguttatus.

Page $₫-8$, Plate V., 16, after view insert as follows: $a$, mentum; $b$, labial rudiment; $c$, maxillary palpi; $d$, maxilla; $e$, labrum; $f$, autenna; $g$, eye; $h$, mandible.

Page 286, line 11, drop initial the one line.

Page 386, line $\vec{i}$, for Comstocki read Comstock.

Page 399, line 17, for specimens read specimen.

Page 411 , line 10, for Michaelson read Michcielsen.

Page 441, line 3 from bottom, for 66 read 68 .

Page 445 , line 10 from bottom, for 57 read 58.

Page 466, line 1 frum buttom, for Cypria read Cypris. 
Article XIV.-Notes on Species of North American Oligocheta. II. By Frank Simth.

\section{ILLINOIS SPECIES.}

The collections of Oligochæta made in connection with the work of the Biological Experiment Station upon the Illinois River, at Havana, contain about thirty species, of which the greater number have been previously described. Two species, one of which must be regarded as belonging to a new genus, are described in this paper.

\section{Pristina leidyi n. sp. (Pl. XXXV.)}

One of the most abundant species of Naidomorpha occurring in the Illinois River at Havana is a member of the genus Pristina, closely allied to P. longiseta Ehrenb., but differing from it in certain characters of sufficient importance to make it necessary to regard it as distinct. In this view I am supported by Prof. Vejdovsky, who has very kindly replied to queries upon the subject. I think it may be the species described and figured by Leidy ('50, p. 44, Fig. 3), and considered by him as identical with the European species $P$. longiseta.

Budding specimens are 4-8 $\mathrm{mm}$. in length when well extended, and sexually mature specimens about $4 \mathrm{~mm}$. The length given by Leidy for specimens measured by him, viz., $\cdot 1$ line, may, I think, reasonably be supposed to apply only to the part anterior to the budding zone, since he states that the "body" is composed of sixteen elongated "articulations," and his figure shows about that number anterior to the budding zone. If this view be correct, the whole length of his specimens would be nearly $4 \mathrm{~mm}$. P. leidyi attains a length of $8 \mathrm{~mm}$. only when there is a chain with three or more budding zones. The diameter is .1 to $.15 \mathrm{~mm}$. The proboscis is much 
like that figured by Leidy, and from its tip to the mouth of the worm measures $.3-.4 \mathrm{~mm}$. It is about $.03 \mathrm{~mm}$. in diameter at the base and tapers slightly toward the tip. The number of somites in sexually mature specimens is about 30 , being subject to variation. The number in specimens with budding zone in an early stage is 24-30, plus an indefinite number of indistinguishable ones at the posterior end.

The dorsal seta agree in number and length with those of Leidy's species. There are three in each bundle, the first ones occurring on II. Those of III are abont $.7 \mathrm{~mm}$. in length, while those of other somites are $.3-.35$ $\mathrm{mm}$. In young specimens each of the bundles usually shows the dorsal setæ of different leneths, only one having attained the normal length, a second being one half or two thirds as long, and a third quite short. In older and sexually mature specimens they are approximately equal. The dorsal bundles contain only capillary setæ, but these differ from the ones ordinarily found in naidiform worms in being slightly curved, and in hav. ing minute slender teeth upon the convex side, which give a serrated appearance to the setre (Pl. XXXV., Fig. (j). The proximal teeth are about $.005 \mathrm{~mm}$. apart, and the serrated condition is most conspicuous near the distal end, the proximal half of the fully developed seta being without teeth. These serrations seem to be a constant - character and are perfectly distinct when examined with high powers, yet they might easily be overlooked, and perhaps escaped Leidy's attention. The ventral setæ (Pl. XXXV., Fig. 5) are in bundles of 5-9, though the more usual number is 6-8. They are about $.05 \mathrm{~mm}$. in length. Sexually mature specimens have one pair of genital setar on each side of VI in place of the ordinary ventral setre. These genital setæ are bifid at the outer extremity and shaped much like ordinary setæ, but are somewhat straighter and about one half longer. 
The brain is slightly longer than wide, and is deeply cleft both anteriorly and posteriorly as in $P$. longisete ('84, Vejdovsky, Taf. II., Fig. 13).

The alimentary tract agrees with that of $P$. longiseta and of Leidy's species. The glandular ventricle is in the anterior part of VIII, and is followed by a narrow part of the intestine which is convoluted in IX and opens into the wider region of the intestine in the posterior part of that somite. In older specimens these regions are very distinct, but in those recently formed by budding the differentiation is much less obvious. As in $P$. longiseta, septal glands are present in III-V, of which those in IV and $V$ are large.

A pair of contractile vascular trunks connects the dorsal and ventral vessels in each of somites III-VII, being situated just in front of the posterior septum in each. While they are all conspicuous, yet those of VI and VII are a little larger than the others, though not so much dilated as those of $P$. longiseta as figured and described by Vejdovsky. A pair of non-contractile vessels branch off from the dorsal vessel just posterior to the brain.

The first pair of nephridia is in IX. An examination of more than thirty specimens with reference to their location has shown no variation in the position of the first pair, but in five instances the ninth somite contained but one nephridium. The next following somites usually contain but a single nephridium, although in eight per cent. of the cases two nephridia were present, and in nine per cent. the nephridia were entirely wanting. In at least ninety per cent. of the instances observed, when but one nephridium was present it belonged to the left side of the somite. In $P$. longiseta the first nephridia are stated to occur in somite $\mathrm{X}$, and, to my knowledge, there is no record of such variability in the number of nephridia in each somite as characterizes $P$. leidyi. The nephridiopores are a little anterior to the ventral setæ and slightly mesad of the same. 
The perivisceral corpuscles are very conspicuous, a fact which is due to the presence of several spherical bodies that nearly fill the cell. The corpuscles are spherical and collected chiefly about the inner ends of the setæ.

In the latter part of July of the present year, 1896, anong a large number of specimens without clitellum and sexually immature, 1 found one individual which had orgaus in VII and VIII, presumably gonads. I have as yet found no sexually mature specimens of $P$. leidyi in their natural environment, but in the latter part of May of the present year I found a few of them among. the progeny of an individual of this species which had been isolated in December of last year and kept with its descendants in confinement at the temperature of an ordinary living room. These worms exhibit uniformity in their reproductive organs, and as they also agree with the specimens above referred to in the presence of organs in VII and VIIl, I have no reason for thinking that their reproductive organs are not normal. My sections, and my observations upon the living specimens enable me to establish several important points concerning them. The most noticeable difference between the reproductive organs of Pristina and those of other Naidomorpha in which these structures have been studied, is the fact that they are located two somites further back in Pristina than in other members of this family.

In $P$. leidyi the clitellum extends from the setæo of VII to those of IX, and is quite thick upon the dorsal portion of VIII and the anterior part of IX. In place of the ordinary ventral setæ in each side of VI a pair of genital setæ appears, as previonsly stated. Ventral sptre of the risual type are present upon each of the neighboring somites. A pair of large multicellular glands without definite lumen is situated in the posterior part of VI. Each of these glands is comnected with the ventral wall of the cœlom and surrounds a pair of genital setæ (Pl. XXXV., Fig. 1 and 4). A pair of testes is pres- 
ent in VII, attached to the ventral wall, just posterior to the spermathece (Plate XXYV., Fig. 4). The c.liated fumels of the sperm-duct are in the posterior part of the same somite, and are quite large, simple, and funnel-shaped, and have their opening directed dor'sad (P'l. XXXV., Fig. 3 and 4). The sperm-duct is short and wide. After entering VIII its course is dorsad, but making a rather short turu it passes ventrad, opening upon the same somite. The walls of the first half of the duct are glandular (Pl. XXXV., Fig. 3), and those of the last half are muscular. The ventral wall of VIII is much thickened in the vicinity of the male pore. The opacity due to the clitellum renders the study of the duct impossible in the living specimen, and I have had to depend upon sections for my knowledge of it. In the specimens sectioned there is no especial enlargement of the lumen to form an atrial chamber. The cavity of VII contains loose spermatozoa, and a single spermsac opens from it and extends through VIII into IX, lying dorsad to the alimentary tract. Ova are contained in IX. A pair of ovaries is situated in VIII, and there seem to be oviducal pores at VIII|IX. In the most anterior part of VII is a pair of spermathecæ, the pores of which are at the anterior margin of that somite. (Pl. XXXV., Fig. 1, 2, and 4.)

The asexual reproduction or budding of $P$. leidy $i$ is in some respects quite different from that observed by Bourne in the species studied by him ('91, p. 354). Unfortunately, I have not been able to obtain any data concerning this phenomenon in $P$. longiseta. $P$. leidyi agrees with other naidiform worms in the general features of the budding process, new somites being developed at the budding zone, an indefinite number of which form the posterior part of the anterior daughter worm, and a definite number ( $\mathrm{z}^{\prime}$ of Bourne, '91, $\mathrm{p}$. $339)$ the anterior part of the posteriol daughter wor'm; but instead of there being a constant, or nearly 
constant, number of somites anterior to the budding zone ( $n$ of Bourne), it is the normal thing in this species for $n$ to vary. The budding zones successively formed in the same worm do not occur at the same place, but a second zone normally occurs one somite nearer the anterior end than the first zone, and the third zone one somite interior to the second zone, and so on. Of course, a limit is soon reached, anterior to which new zones are not formed. This is usually at XII/XIII or XIII/XIV. When this limit is attained, the next new zone is formed at some point posterior to the position of the last zone. The following data, taken from the records of a large number of worms which were isolated and reared in confinement, will serve as an illustration of the usual order of appearance of budding zones. A specimen isolated December 2, 1895, had a chief budding zone at XIV| $\mathrm{XV}$, and a younger one at XIII/XIV. December 5 , the beginning of a still younger zone at XII|XIII was visible, while the posterior division of the worm had a budding zone well started at XVI|XVII, and a younger one at $\mathrm{XV} / \mathrm{XVI}$. December 7 , the posterior division had been freed, and the chief budding zone of the anterior division was at XIII|XIV. December 11, another worm had been freed, and the only budding zone of the anterior division was at XII|XIII. December 19, another worm had been freed, and a new budding zone started at XIII/XIV, in the regenerated portion of the anterior division. Of the six individuals represented in the chain as observed December 5, all but one had become free by December 19. Not only is $n$ variable normally, but the position of the first budding zone in the newly formed worms is variable. I have found that in the case of individuals kept in confinement, and so under abnormal conditions, there was a tendency for the first budding zone of new individuals to appear further back than in those living in larger bodies of water. Of 
one hundred specimens observed under normal conditions, or after but brief captivity, fourteen had the first budding zone at XV|XVI, sixty-nine at XVI|XVII, sixteen at IVII/XVIII, and one at XVIII|XIX. In no instance have I found Bourne's $z^{\prime}$ to be other thau seven. I may state here that after numerous observations upon several species of naidiform worms I have found that $n$ is extremely variable in individuals of the same species, and, also, in a less number of species, that the number of somites in the sexually mature worm is not constant for a species.

Mesoporodrilus asymmetricus $\mathrm{n}$. g. et $\mathrm{n}$. sp.

XXXVI., and Pl. XXXVII., Fig. 11 and 12.)

The following description is based upon two specimens of a lumbriculid species which were found in July of the present year in the sand of the east shore of Quiver Lake, near its foot, and in a situation where small springs of water kept the sand wet and cold. The specimens were received at a time when a study of the living worms could not be made, and they were immediately fixed and preserved. One of the specimens was not in a very good condition, and was chiefly valuable in confirming the observations upon some of the more important characters of the other.

The worms are without pigment, and quite delicate in appearance. They are $30 \mathrm{~mm}$. in length and $.5 \mathrm{~mm}$. in diameter, the number of somites in one apparently complete speciinen being 65 . They are provided with a proboscis that in length equals the diameter of the first somite. There are four pairs of pointed setæ on each somite (Pl. XXXVI., Fig. 9). The clitellum extends from the middle of IX to the middle of XIII, and is conspicuous.

The pharynx extends through III and IV (PI. XXXVII., Fig. 11). The epithelium of the dorsal half of its wall is thick and ciliated (Fig. 12), although thinner along the median line of the fourth somite than elsewhere. 
The ventral half of the wall is rery thin and without cilia. In somite $V$ the walls of the alimentary tract become nearly uniform in thickness and ciliated throughout. The lumen in this somite is quite narrow. In the following somites the intestine is sacculated. Beginning with the seventh somite it is invested by a nearly continuous sheath of blood, outside of which is the layer of chloragogue cells. The muscles connecting the pharym with the body wall are very weak and few in number (Fig. 11). There is no glandular tissue forming pharyngeal and septal glands. There is a similar absence of such glands in Eclipidri'us frigidus Eisen ('9.5, Eisen, p. 86). $\Lambda$ few deeply-staining cells are situated on some of the blood vessels of the region, but none upon the pharyngeal muscles.

My knowledge of the circulatory system of this species is very imperfect, owing chiefly to lack of opportunity for studying the worms in the living state. The ventral ressel is forked near the septum V|VI. None of the vascular trunks connecting the dorsal and ventral vessels are especially enlarged. In the anterior part of each of a few of the anterior somites a pair of vessels invested by gland cells connects the ventral vessel with the dorsal part of the intestinal sinus; while in the posterior part of the somite a pair of slender vessels without investing gland cells and having a somewhat tortuous course connects the dorsal and ventral vessels. ' pair of these connecting vessels from somite $\mathrm{I}$ extends backward through several somites, veing closely associated with the reproductive organs contained therein. In the posterior part of the worm there are two pairs of lateral vessels in each somite; one situated anteriorly, the other, posteriorly. Botl pairs branch off from the dorsal vessel, from which they extend laterad, each ressel closely following the body wall. They are similarly inrested by gland cells, and have short coecal diverticula, but the vessels of the posterior pair, unlike the anterior, unite with the rentral vessel. 
The first pair of nepliriclia is in VII, and the nephridiopores are situated in front of the ventral setæ. Albumen glands are wanting.

The reproductive organs of this species are in some respects quite remarkable. One of the specimens had these organs well developed; the other had passed the stage of sexual activity, but still had most of the organs present, though reduced in size. One pair of testes is present in $\mathbf{X}$. The male efferent apparatus is developed upon only one side. The male pore is upon the midventral line in the posterior part of $\mathrm{X}$ (Pl. XXXVI., Fig. 7). As this condition exists in each of the specimens, it cannot be ascribed to individual abnormality. The funnel of the sperm-duct is in the posterior part of X. I have been unable to trace the part of the spermduct connected with the funnel, but the distal part has peculiarities of structure closely allying it to the similar organ in $E$. frigidus. An enlarged reservoir extends through XII-XIV (res., Fig. 7). It has a thick wall consisting of a thin epithelial layer and a thick layer of longitudinal muscular tissue. Outside of the muscular layer is a layer of small deeply-staining cells, which in some places are scattered. This layer is nowhere more than one cell in thickness. The reservoir is not constricted by the septa of the somites through which it passes. Surrounding the reservoir, and connected with it, is a thick layer of tissue of a reticulate character, which is constricted by the septa. The posterior end of this reservoir ends blindly, while the anterior end is continuous with a smaller tube which extends forward and inward as far as the middle of XI, and then, making an abrupt turn outward, passes posteriorly half way to septum XI|XII, where, with another abrupt turn, it extends anteriorly and is continuous with a larger portion of the duct corresponding to the "prostate and atrium" of $E$. frigidus. The part of this enlarged portion which is situated in XI (pr., Pl. XXXVI., Fig. 7), and which be- 
cause of its relations to the other parts of the sperm-duct corresponds to the "prostate" of E. frigidus, has thick walls with layers corresponding to those of the reservoir and the comnecting duct, the chief difference hetween the walls being that in the former the ephithelial layer is much thicker than in the two latter. 'There is no layer of elongated glandular cells like that of the prostate of $E$. frigidus. At a point just anterior to the septum X/XI is an enlargement of the duct and an expansion of the lumen to form a small chamber (at., Fig. T), in which is a marked change in the lining epithelium, this layer becoming much thimner and the cells more scattered. The terminal portion of the duct extends from the chamber above referred to, ventrad to the male pore. The structure of this portion of the duct leads me to believe that this worm has an eversible penis. A mass of glandular cells ( $g l . c \%$., Fig. 7 ) is closely associater with the sperm-duct at its extermal openiug. It consists of au aggregation of elongated mirellular glands opening to the exterior upon the surface of the body at the male pore. They are much like glands similarly situated in some of the Lumbricida. The nerve cord is slightly displaced in the region of the male pore, where it leares the middle of the rentral floor and lies on one side of the sperm-duct. There is but one spermsac, and this extends as far back as XXI, lying partly beneath and partly to one side of the alimentary tract. The reservoir of the sperm-duct with its external sheath of tissue is partially surrounded by the cavity of the sperm-sac. In somites X-XVII the alimentary tract is upon one side of the body, being displaced by the large mass consisting of sperm-sac and sperm-duct. There is one pair of ovaries, in XI. They are large, irregularly bent, and project part way into XII. The oviducts are two in number, short, and open to the exterior at XI। XII (Pl. XXXVI., Fig. 8). Two spermathecæ are situated in IX. but instead of heing paired they are both 
upon the same side of the somite, and their external pores are in the mid-ventral line (Pl. XXXVI., Fig. 10), one behind the other. This unusual state of things exists in both specimens.

M. asymmetricus has several important features allying it closely to $E$. frigiclus, and, in my opinion, should be included with it in the subfamily of Lumbriculidæ proposed by Eisen ('95, p. 84) for the latter species. The points of resemblance are the character of the alimentary tract and the absence of pharyngeal and septal glands, some features of the circulatory system, the structure and extent of the sperm-duct, the extent of the sperm-sac, and, finally, the position of testes, male pore, and ovaries. The median position of the pores of the spermathecre and sperm-duct and the numerical asymmetry of these organs are unique and difficult to account for.

FLORIDA SPECIES.

Through the kindness of $\mathrm{Mr}$. Adolph Hempel, of the Biological Station staff, I received in March of the present year a large number of living Oligochæta from Florida. Among them were sexually active specimens of four different species; viz., Diplocardia eiseni Michaelsen, ('94, Michaelsen, p. 184), Allolobophoru giesteri Ude, ('95, Ude, p. 127), Sparganophilus eiseni Smith, ('95. Smith, p. 142), and a species of Microscolex, apparently undescribed. Among the specimens of Diplocardia eiseni are a few quite young individuals not so heavily pigmented upon the anterior end as are the adults, and in these the double character of the dorsal vessel in the first fifteen somites, first noticed by Ude ('95, p. 136), is quite obvious. It is not visible in the mature living worms. The specimens of Sparganophilus are much smaller than those found in Illinois, being but half as long and very slender. I have not as yet been able to discover any anatomical characters that distinguish them from $S$. eiseni. 
Microscolex hempeli n. sp. (Pl. XXXTII., Fig. 13, and Pl. AXXYll.)

This species was represented by eleven specimens, mostly mature. They were found near Quincy, Florida, under a manure heap.

They are not pigmented, but, like Eisen's Deltania species, are pale and rather deli ate. Alcoholic specimens killed well exteuded are $35-55 \mathrm{~mm}$. in length and 1-1.5 $\mathrm{mm}$. in diameter. The number of somites in seven specimens averaged 73 , with extremes of 63 and 78 . The prostomium extends over about half the first somite. The clitellum is upon XIII-XVII, but extends a shorter distance upon the ventral surface of XVII than elsewhere, the outline forming a sinus as in $H$. nova selandice ('93, Beddard, Fig. 1). It is complete and nearly as thick upon the ventral as upon the dorsal surface (Pl. Ixxvil., Fig. 14). Small genital papillie are present but difficult to see upon the entire worms, and I have studied them only upon sectioned specimens. Their situation is quite variable. In one specimen there is a pair of papillæe on $\mathrm{X}$ and a single one on XI; a second specimen has them similarly placed on $\mathrm{I}$ and XI, and also has a pair on IVIII; while a third sperimen luas none on $\mathrm{X}$ or $\mathrm{XI}$, but has a pair on the anterior part of XYII.

The setæ are paired, and those of the inner couples converge toward the male pore, as in the species included l,y Eisen in lis genus Deltania ('9t, p. 22). In the somites posterior to XIX (See Fig. 13, Pl. XXXYII.) the distance between the setæe of a ventral couple is almost exactly equal to that between the setæe of a dorsal couple, and is abont two thirds of that between those couples, and nearly as great as that between the ventral couples. Thus, calling the distnnce between the inner setæ $(1-1)$ 12, then the distance between the setæo of a ventral couple is 10 , that between the ventral and dorsal couples is 15, that between the 
setie of a dorsal couple is 10 , and that between a dorsal comple and the mid-dor'sal line is 22-24. In the anterior somites the setæ of a ventral couple are a little nearer together than those of a dorsal couple. 'The dorsal setie are in the dorsal half of the worm. Setre of the usual shape and size occur in the clitellar region as elsewhere (Pl. XXXVII., Fig. 13). The ordinary setæ are about $.16 \mathrm{~mm}$. in length. The penial setæ are nearly four times as long, very slender, and slightly curved outward. They are upon XVII, and are only one sixth as far apart as those of the ordinary ventral couples. There are no dorsal pores.

The buccal cavity is everted in alcoholic specimens. The pharynx is thick ouly upon the dorsal side (Pl. XXXVIII., Fig. 17). In somite $\mathrm{V}$, as shown by septa, but pushed back to VI, as indicated by external division, is a slightly developed grizzard (giz., Fig. 17). This has a layer of circular nuscle fibers slightly thicker than that of the body wall of the same somite, but not nearly as powerful as in some $\Lambda$ canthodrilidæ. The cesophagus continues to XVI, where it joins the greatly enlarged intestine. Septal glands are present in V-VIII, those of VII and VIII being small, and those of V and VI largèr. Figure 17 was drawn from median sections, and consequently show's only small parts of the septal glands.

The first nephridia are in II, and those of II-IV each have a nephridiopore anterior to seta 4 . 'Those of $\mathrm{V}$ and the following somites each open anterior to and a little ventrad to seta 3 , the nephridiopores being almost exactly at the ends of the transverse diameter of a cross section of the body. They all possess a bladder or' vesicle next to the wall.

The "hearts" are large and in X-XII.

The testes have the usual situation in X and XI. The small and slightly lobulated sperin-sacs are in XI and $X I I$, and are attached to the anterior septum of their respertive somites a little below the osophagus. The 
ciliated funnels of the sperm-rlucts have the usual situation in $\mathrm{X}$ and $\mathrm{XI}$. The sperm-ducts are slender and without convolutions. They meet in XII and extend to XVII, those of either side lying close to each other and passing through each somite just laterad of seta 2 (sp. d., Pl. XXXVlll., Fig. 14). During their course they lie upon the muscle layer of the body wall, without entering it, until they are in the neighborhood of the male pore. When they have reached the vicinity of the penial setre they enter the muscular wall and unite, and the common duct passes around the posterior side of the duct of the prostate gland and the outer penial seta and opens to the exterior between, and slightly posterior to, the penial setæ (Pl. XXXVIII., Fig. 15 and 16). One pair of prostate glands is present in XVII. The glandular part is tubular and slightly smaller in diameter in the distal region, where it is bent, but not helix-like. IIore frequently the distal portion projects into XVIII. The wall is composed of long glandular cells, of which many are somewhat bent and irregular. Although I have sturlied thin sections carefully, I cau distingu'sh no differentiation into two layers. If there is any inner epithelial layer at all, it is very slightly developed and not continuous. I have found the same condition in sections of each of several individuals. The muscular duct is slightly longer than the setal sac near it, and opens to the exterior just outside the outer penial seta. The penial setæ and the pore of the duct of the prostate are very nearly in a straight line, with the male pore between the setæ and the prostate-duct pore just outside the onter penial seta (Fig. 15 and 16). One pair of spermathecæ is present in IX. In some specimens one spermatheca projects into VIII, but the pores are upon IX in each instance. These pores are at the anterior margin of the somite and in line with seta 1 . The spermathecæ extend from one third to one half the way across the somite, each having a somewhat 
elongated sac, and a distinct duct about one half as long' as the sac. 'Two diverticula communicate with the duct about midway of its length. They are approximately equal and one half as long as the spermatheca. Each has a narrow duct and an elongated sac. The ovaries have the usual situation in XIII. 'There are no ovisacs. The oviducal pore of each side is anterior to seta 1 and in line with it.

In M. hempeli, characters are combined which seem to bring the genera Rhododrilus and Deltania very near together and to emphasize the necessity of combining them with Microscolex as Beddard has done ('95, p. 228). Dr. Eisen has expressed his opinion in favor of the same course in a letter recently received, as has also. Dr. Benham.

The presence of Microscolex, Sparganophilus, and Diplocardia in Florida serves to bring the earthworm fauna of that region into close relationship with that of the more western parts of this country and South America. Champaign, Noveuber 6, 1896.

\section{LIST OF PAPERS CITED.}

93. Bedpard, F. E.-Some New or Little-known Oligochreta. Proc. Roy. Phys. Soc. Edinb., XII., pp. $30-45$.

95.

Preliminary Account of New Species of Earthworms belonging to the Hamburg Museum. Proc. Zool. Soc. London, Pt. II., pp. 210239.

91. Bourne, A. G.-Notes on the Naidiform Oligochæta; containing a Description of New Species of the Genera Pristina and Pterostylarides, and Reinarks upon Cephalization and Gemmation as Generic and Specific Characters in the Group. Quart. Journ. Micr. Sci. (n. s.), Vol. XXXII.,.pp. 335, 356. Pl. XXVI. and XXVII. 
'94. Eisex, ('.-On California Eudrilitle. Mem. Calif. Acarl. Sci., Tol. II., No. 3, pp. 21-(i2. PI. XII.XXIX.

'95. L'Pacific Coast Oligocheta, I. Mem. Calif. Icad. Ści., Vol. II., No. 4, pl. (63-90. Pl. IXI.-XIX.

'50. Leivr, J.-Descriptions of some American Annelida abranchia. Jomrn. Aead. Nat. Sci. I'hil., Tol. II., 2d ser., pp. 4:3-50. Pl. II.

94. Michaelsox, W.-Die Reg'enwurm-Fanna von Florida und Georgia. Zool. Iahrb., Abth. f. Syst., Bd. VIII., 2 Heft, pp. 177-194.

'95. Surth, F.-A Preliminary Account of two New Oligochieta from Illinois. Bull. Ill. State Lab. Nat. Hist., Vol. IV., Art. V., pp. 138-148.

'95. Uds, H.-Beiträge zur Kenntnis der' Enchytrieiden und Lumbriciden. Zeit. f. wiss. Zool. Bd. LXI., 1 Heft, pp. 111-141. Taf. VI.

'84. Vesdorskr, F.-System und Morphologie der Oligochæten. 166 pp. 16 Taf. 


\section{EXPLANATION OF PLATES.}

ABbieviations.

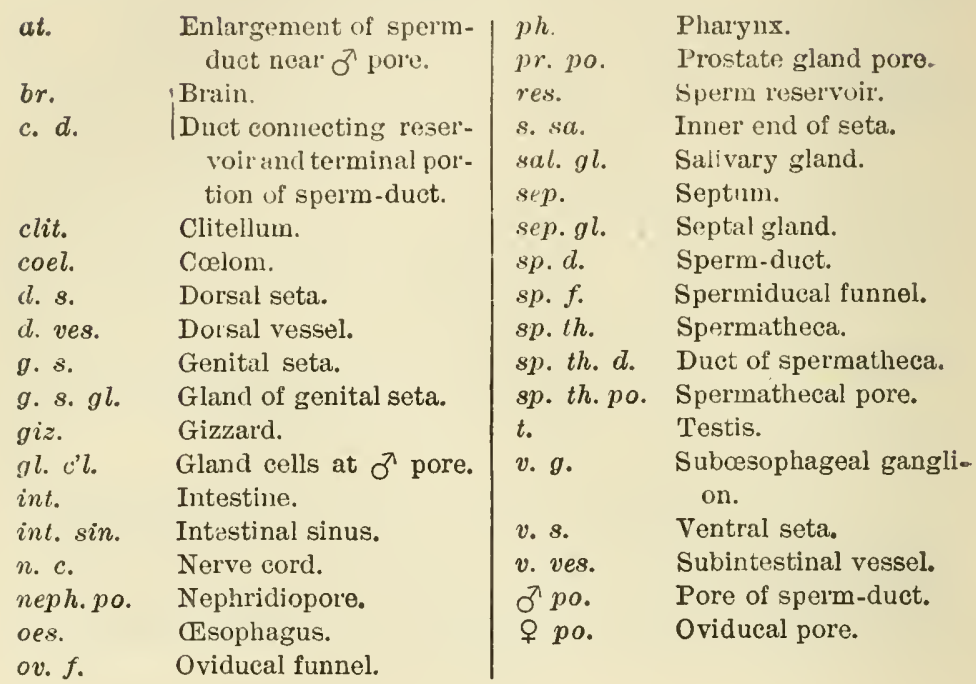

\section{Plate XXXV.}

Pristina leidyi.

Fig. 1. A slightly oblique transverse section passing through the glands of the genital setæe in the posterior part of VI, and through the duct of one spermatheca in the anterior part of VII. The septum is not shown. $\times 335$.

Fig. 2. 'Transverse section near the middle of VII, passing through the snermathecr. $\times 335$.

Fig. 3. A slightly, iique transverse section passing through the spermiducal funnel in the posterior part of VII and the glandular part of the sperm-duct in the anterior part of VIII. $\times 335$.

Fig. 4. Diagram showing the arrangement of part of the reproductive organs. Setæ are relatively too small.

Fig. 5. A ventral seta. $\times 550$.

Fig. 6. Distal portion of a dorsal seta. $\times 1000$. 


\section{Plate Misti.}

Mesoporodritus asymmetricus.

Fig. 7. A median longitudinal section reconstructed from several sections. $\times 80$.

Fig. 8. Oviducal funnel and pore. $\times 210$.

Fig. 9. $\Lambda$ seta. $\times 210$.

Fig. 10. Ventral portion of a transverse section through IX, showing the position of the pore of one of the spermathecse. $\times 190$.

\section{Plate XXYVII.}

Mesoporodrilus asymmetricus.

I'ig: 11. Median longitudinal section of anterior end, from several sections. The proboscis of this specimen harl been lost, but its position, as slown by the injury to the wall of the prostomium, is indicated by dotted lines. $\times 80$.

Fig. 12. A cross section of the pharynx. $\times 120$.

$$
\text { Microscolex hempeli. }
$$

Fig. 13. Diagram showing the arrangement of the ventral setæ in the anterior part.

\section{Plate NXIYIII. \\ Microscolex hempeli.}

Fig. 14. Cross section from the region of the clitellum. $\times 33$.

Fig. 15. From a superficial frontal section showing the relations of the genital setæ and pores of one side. $\times 350$.

Fig. 16. Portion of a transverse section through the male pore of one side. $\times 200$.

Fig. 17. Meclian longitudinal section of a specimen with lips everted. $\times 30$. 